\title{
Autoantibodies against Muscarinic Acetylcholine Receptor on Exocrine Glands in Sjögren Syndrome
}

\section{Silvia Reina and Enri Borda*}

Pharmacology Unit, School of Dentistry, University of Buenos Aires and National Research Council of Argentina (CONICET), Buenos Aires, Argentina

\begin{abstract}
These investigations demonstrate that serum antibodies against muscarinic acetylcholine receptors (mAChR) in primary Sjögren syndrome (pSS) and associated Sjögren syndrome (aSS) bind and activate both cholinergic receptors of $\mathrm{M}_{3}$ in salivary gland and $\mathrm{M}_{1}$ in neonatal myocardium and in the cerebral frontal cortex area subtypes; triggering the production of the second messengers and proinflammatory mediators related to mAChR activation. In this way the cholinergic autoantibodies damages these receptors, which thus starts acting as an antigen. On this basis $M_{3}$ and $M_{1}$ mAChR IgG can be considered new markers of pSS/aSS allowing the differentiation between dry eye and mouth of autoimmune and non-autoimmune nature. Given that cholinergic autoantibodies also deregulate the parasympathetic system of the target organs, they can also be seen as a new factor contributing to the etiopathology of the syndrome.
\end{abstract}

Keywords: Autoantibodies; Anti-M ${ }_{3} \mathrm{mAChR} \mathrm{IgG;} \mathrm{NO;} \mathrm{PGE}_{2}$

\section{Introduction}

Sjögren syndrome (SS) is a devastating autoimmune illness with heterogeneous clinical expressions. These expressions reflect not only different etiologic factors, e.g. genetically and immunological abnormalities, but also the deregulation among them as well as the dysfunction of the parasympathetic system. They have the following cardinal clinical symptoms: xerostomia and xerophtalmia at the level of the exocrine glandular system [1], cognitive impairments such as perception, attention and executive function deficits [2] at the level of the cerebral frontal cortex, complete congenital heart block at the level of neonatal myocardium [3]. These alterations are reliable predictors of long term disabilities.

Numerous theories have been formulated and tested and continue to compete for supremacy as the essential explanation for why patients suffer from periodic episodes of altered exocrine secretion and remission and why these episodes typically result in same social and cognitive dysfunction in the chronic course of the SS. Relevant in this sense, are those theories shifting their attention to the organ specific immunological deregulation involved in the manifestations and the chronic course of the disease [4-7], and to the clinical features of an immunological or inflammatory disease $[8,9]$.

In this line, anti-salivary/frontal antibodies have been shown to be involved in autoimmune disorders with cognitive manifestations in lupus [10] and in SS [11]. It should be noted that the main autoantibody involved in these disorders are the $m A C h R$ subtype $M_{3}$ and $M_{1}$ [11].

In this article we will examine the role of cholinergic autoantibodies subtypes $M_{3}$ and $M_{1}$ and its relationship with the signs and symptoms of SS and its pathological implications in SS.

\section{Autoimmune Basis of Sjögren Syndrome}

Primary SS occurs in 0.1 to $3.0 \%$ of the population in general.The disease is more common among women (female/male ratio 9:1) aged 40 to 60 years old and is rarely seen in children and adolescents.

There are many factors to be considered in the etiology of the disease such as genetic factors in which the B cell [12] or the B-cell activation factor (BAFF) and the tumor necrosis factor (TNF) are implicated. Furthermore, it is presumed that the genetic predisposition leading to the increment of type I IFN may explain why this interferon is present in the salivary gland and peripheral blood in pSS patients. HLA-B8 of HLA-DW3, HLA-DR3 and DRW52 have also been reported in pSS patients $[13,14]$. Other factors responsible for the development of pSS are viral infections -mainly, Epstein-Barr virus (EBV), cytomegalovirus (CMV) and Hepatitis C virus (HCV) [15]; neurohormonal disturbances in sex hormones [16]; environmental factors causing the disorganization of glandular epithelial cells, which provoke local innate immune response and activate the toll-like receptor (TLR) pathway involving cell apoptosis [5]; the stimulation of the dendritic cells responsible for the production of INF, which, in turn, leads to the proliferation and the differentiation of $B$ cells and to the production of autoantiboidies.

Nowadays autoimmunity is recognized as a very important factor responsible for the development of the disease $[17,18]$. In this line, oral and eye sicca symptoms provoking a decrease of the exocrine glandular function are taken as evidence of autoimmunity with the presence of autoantibodies to Ro/SS-A (Ro52, Ro60) or La/SS-B [19,20]. These autoantibodies are non organ specific and their role in the pathogenesis of SS was not been understood yet. Some explanations suggest that Ro60 and La autoantigen unlike Ro52 are involved in triggering and maintaining the tissue specific autoimmune response in pSS. This indicates that Ro60 and La autoantigens contribute to the antigen driven immune response and to the production of these autoantibodies. This idea is supported by a further research that documents the production of local anti Ro system and anti La autoantibody in the submandibular and parotid gland of pSS patients [21]. Subsequent studies [22] demonstrate that lymphocytes' infiltration in salivary gland is organized in the form of an ectopic germinal centre, in which anti-Ro60, anti-Ro52 and anti La autoantibodies are produced. They also show that these autoantibodies participate in the cell apoptosis [22]. The sustenance of these phenomena in time is responsible for the destruction of the gland and other extraglandular manifestations. However, glandular epithelial cells are also infiltrated by macrophages, plasma cells, T cells [23] and

*Corresponding author: Enri Borda, Pharmacology Unit, School of Dentistry, University of Buenos Aires, Marcelo T. de Alvear 2142, 4B,1122AAH, Ciudad Autónoma de Buenos Aires, Argentina, Tel: +54-11-4964-1276; E-mail: enri@farmaco.odon.uba.ar

Received October 30, 2014; Accepted November 14, 2014; Published December 22, 2014

Citation: Reina S, Borda E (2014) Autoantibodies against Muscarinic Acetylcholine Receptor on Exocrine Glands in Sjögren Syndrome. Dentistry 4: 265 doi:10.4172/2161-1122.1000265

Copyright: ( 2014 Reina S, et al. This is an open-access article distributed under the terms of the Creative Commons Attribution License, which permits unrestricted use, distribution, and reproduction in any medium, provided the original author and source are credited. 
dendritic cells [24]. T cells are balanced toward Th1 and Th17, which release IL-17 [19] and promote the generation of pro-inflammatory cytokines as a main nitric oxide (NO) [25] and as prostaglandins (PG) [11]. This is why $\mathrm{PGE}_{2}$ and NO together with IL-6 are seen as crucial factors of the maintenance of the inflammatory process and it's becoming chronic [26].

It is important to notice that, antinuclear antibodies (ANA) together with the rheumatoid factor (RF) and anti centromere antibody (ACA) are frequently found in patients with pSS in the early stages of the disease and at a younger age $[20,27,28]$. These antibodies are not specific to SS, but in a way, show a local response to autoantigens derived from salivary glands aggressors, which produce these antibodies at the level of the local system [29].

These immunological events together with histological studies of salivary lip glands showing a progressive focal infiltration of mononuclear lymphoid cells cause the replacement of the glandular epithelial cells and the subsequent reduction of saliva secretion [30,31]. In this vein, germinal centre like structures in the gland with elevated titres of RF, increased IgG levels and high focus score (FS) equal or more than one have been identified [32]. A positive biopsy is then given when FS has 50 inflammatory cells in a $4 \mathrm{~mm} 2$ salivary lip glandular section $[33,34]$.

\section{Action of Anti-muscarinic Acetylcholine Receptors Antibodies in Patients with SS}

Experimental and clinical studies suggested the presence of cardiac anti-M $\mathrm{M}_{1} \mathrm{AChR}$ antibodies in mothers with SS whose children have congenital heart block [35-39] and the presence of IgG against $\mathrm{M}_{3} \mathrm{mAChR}$ in sera of patients with pSS that interact with rat exorbital lacrimal glands $[1,25]$ and rat parotid gland [40]. The presence of IgG against $M_{1}$ and $M_{3} m A C h R$ was also found in sera of patients with pSS interacting with rat cerebral frontal cortex [41].

Antibodies to neurotransmitter receptors have been described in idiopathic dilated myocardiopathy [42] and in chagasicmyocardiopathy [43]. The latter is clinically characterized by a dysautonomic syndrome related to the progressive blockade of parasympathetic neurotransmitter receptors, with a denervation of both adrenergic and cholinergic branches of the autonomic nervous system [44]. We described the presence of antibodies against cholinergic receptors in cardiac, exocrine glands and cerebral frontal cortex in SS and proposed that the deposit of these autoantibodies could lead to a progressive blockade of these receptors behaving as a partial agonist and inducing desensitization and/or down-regulation $[45,46]$.

Thus, Sjögren's autoantibodies appear to be reactive to the $M_{1}$ cholinoceptor ofneonatal heart, suggesting the multiplicity of the autoimmune responses in primary SS. Congenital heart block is thought to result from the transplacental passage of maternal autoantibodies that could cause an inflammatory reaction in the developing heart of the fetus resulting in severe defects of conduction [47,48]. In this regard the hypothesis that cholinoceptor autoantibodies can act as a "sensitizing" or "predisposing" condition present at a critical period during the development of the fetal electroconduction system seems reasonable. Being pSS one of the immune disorders strongly associated with congenital heart block, these findings suggest that $M_{1}$ muscarinic cholinergic autoantibodies are another factor that could be involved in the pathogenesis of congenital heart block associated with primary SS in addition to ribonucleoprotein antibodies (anti-Ro/SSA and anti-La/SSB).

We have already reported autoantibodies against rat salivary and lacrimal glands $\mathrm{M}_{3} \mathrm{mAChR}$, which trigger parasympathetic-receptormediated biological effects $[25,39,49,50]$. We have demonstrated that they are able to recognize a synthetic peptide corresponding in amino acid sequence to the second extracellular loop of the human $\mathrm{M}_{3} \mathrm{mAChR}$. The distribution of the amino acid sequence between rat and human $M_{3}$ synthetic peptide has a great homology (84\%). An isolated fraction from SSIgG enriched in anti- $\mathrm{M}_{3}$ peptide antibodies could reproduce the effects of the corresponding whole immunoglobulins. This fact strongly suggests a prominent role of anti- $\mathrm{M}_{3}$ peptide antibody in the mAChR-mediated effects of total SS IgG. In addition, the synthetic peptide involved selectively suppresses the biological effects of SS anti- $\mathrm{M}_{3}$ peptide autoantibody and the corresponding total IgG. This supports the view that the second extracellular loop is not only the main immunogenic region of the receptor [51] but can be considered essential for the biological action of these autoantibodies. We also demonstrated that there is an association between the existence of circulating anti- $\mathrm{M}_{3} \mathrm{mAChRIgG}$ autoantibodies, the presence of ocular and mouth symptoms, gland surface alterations and a selected number of antibodies detected in SS. These finding points to these autoantibodies as a valuable marker for dry eye and mouth associated to SS. In addition, we have shown a good correlation between lacrimal function, serum IL-2 receptor, ANA, and RF in SS dry patients [52]. This process could lead to a progressive blockade of $\mathrm{mAChR}$ which, in turn, induces dry eyes and mouth, the classical signs of SS.

Further evidence is required to show persistent abnormal levels of IgGs in forebrain tissues of SS patients in order to understand the effect of these autoantibodies on the cognitive deficit in these patients. Towards this understanding we postulate on the basis of our results that the early agonistic-promoting activation of $\mathrm{M}_{1}$ and $\mathrm{M}_{3} \mathrm{mAChR}$ initiated by antibodies bind to cerebral frontal cholinoceptors persistently. Later, the agonistic activity displayed by these autoantibodies induces desensitization, internalization and/or intracellular degradation of the $\mathrm{mAChR}$, leading to a progressive decrease of cerebral $M_{1}$ and $\mathrm{M}_{3} \mathrm{mAChR}$ expression and activity. Furthermore, IgG antibodies binding to mAChRs modify spare receptors'affinity, sensitivity and expression in brain tissue. Therefore, it could be hypothesized that the central nervous system manifestations, which are apparent during SS, might be induced by an impaired response to the cholinergic endogenous neurotransmitter's stimuli due to $\mathrm{mAChR}$-antibody being fixed to its receptors [41,53-55].

Antibodies to muscarinic receptors, detected by functional methods or the use of synthetic peptides, have been described in SS patients. The functions of mAChR $M_{1}$ and $M_{3}$ subtypes are numerous, the most noteworthy being their function as the main receptors stimulated by acetylcholine released by postganglionic fibers in the parasympathetic nervous system [56]. It was demonstrated that the agonist-mediated stimulation of $\mathrm{mAChR} \mathrm{M}_{1}$ and $\mathrm{M}_{3}$ subtypes in rat salivary, lacrimal glands leads to saliva and tears production [57]. Subsequent studies revealed that they are fundamental for the parasympathetic regulation of exocrine secretion [58]. Further functional studies led to the assumption that these $\mathrm{mAChR} \mathrm{M}_{1}$ and $\mathrm{M}_{3}$ subtypes antibodies contribute to sicca manifestations, potentially via direct blockade of parasympathetic neurotransmission [17,59].

Fixation of IgG anti $\mathrm{M}_{3} \mathrm{mAChR}$ autoantibodies of patients with pSS has functional implications for the exocrine glands. This is because the antibody limits not only parasympathetic stimulation with decreased salivary and lacrimal function, but also the effectiveness of endogenous agonists [60]. It is well known that the activation of $\mathrm{M}_{3} \mathrm{mAChR}$ generates the secondary messenger's inositol phosphate $\left(\operatorname{Ins}_{3}\right)$ and 
prostaglandin $\mathrm{E}_{2}\left(\mathrm{PGE}_{2}\right)$. Each of these metabolites influences salivary and lacrimal secretion by mobilising calcium from intracellular stores and regulating the absorption of ions and water [61]. They also play a key role in the pathophysiology of chronic inflammation [62]. These facts have led us to think that the damage and inflammation in the exocrine glands commonly seen in SS patients might be a consequence of the production of pro-inflammatory mediators induced by antibody$\mathrm{mAChR}$ interaction on gland membranes.

In the salivary glands, the basal lamina of the acini is connected to the cytoskeleton of acinar cells via integrins in the basal plasma membrane [63,64]. Matrix metalloproteinase-3 (MMP-3) degrades components of the basal lamina [64], and might be involved in the loosening of cell anchorage to the basal lamina. As a consequence of such changes, inhibition of the proliferation, differentiation and regeneration of epithelial cells [65], as well as activation of apoptosis $[66,67]$, may account for salivary-gland damage. Patients with pSS show elevated levels of MMP-3 in their saliva [68].

Prostaglandins (PGs) have been implicated in normal cellular processes as well as in pathophysiological conditions such as inflammation $[39,69]$. Nitric oxide (NO) plays a key part in the pathophysiology of chronic inflammation and in the neurodegenerative process [38,70-72]. $\mathrm{PGE}_{2}$ is synthesised by cyclooxygenase (COX) and prostaglandin $\mathrm{E}$ synthase (PGEs) in vivo; the two enzymes catalyse the reaction of transformation of arachidonic acid (AA) through $\mathrm{PGH}_{2}$ into PGE. The two isoforms of COX (COX-1 and COX-2) and PGEs [cytosolic (cPGEs) and membrane (mPGEs)] have been identified. In general, COX-1 and cPGEs are constitutively expressed in almost all tissues and have haemostatic effects, whereas COX-2 and mPGEs are inducible enzymes that are expressed in response to inflammation [73]. $\mathrm{PGE}_{2}$ has been shown to be part of the signalling events involved in $\mathrm{M}_{3} \mathrm{mAChR}$ activation $[49,71,74]$.

Previous studies analyzed the role of antibodies using microspectrofluorometry and surface the plasmon resonance-based optical biosensor system (BIAcore system). They showed that antibodies against the third extracellular domain of $\mathrm{M}_{3} \mathrm{mAChR}$ have an inhibitory activity against carbachol-induced calcium influx in human salivary gland cell lines [75].

Other authors reported that IgG from patients with pSS reduced the expression level of $\mathrm{M}_{3} \mathrm{mAChR}$ in the membrane, inhibited carbacholinduced calcium transients in human salivary gland cells and decreased membrane clathrin expression. These results suggest that IgG from SS patients induce internalization of $\mathrm{M}_{3} \mathrm{mAChR}$ partly through a clathrinmediated pathway. They also provide support to the notion that anti$\mathrm{mAChR} \mathrm{M}_{3}$ antibodies cause salivary dysfunction in patients with SS via both a reduction of calcium influx and the down-regulation of $\mathrm{M}_{3} \mathrm{mAChR}$ molecules on epithelial cells of salivary glands [76].

All these results suggest a complex interplay between different factors involved in innate and adaptive immunity, glandular $\mathrm{M}_{3} / \mathrm{M}_{1} \mathrm{mAChR}$ and the corresponding release of second messengers provoked by the binding and activation of this receptor by the SS autoantibodies. These results could also provide a basis to understand the link between autoimmunity and exocrine parasympathetic dysfunction in SS. This link could be further explained by the early agonist-promoting activation of salivary and lacrimal gland $\mathrm{M}_{3} \mathrm{mAChR}$ initiated by autoantibodies binding to, and persistently activating cholinoceptors. This result is accompanied by the production of large amounts of pro-inflammatory substances, contributing to inflammation. The agonist activity displayed by anti- $\mathrm{M}_{3} \mathrm{mAChR}$ peptide antibodies could subsequently induce desensitisation, internalisation and/or intracellular degradation of glandular $\mathrm{M}_{3} \mathrm{mAChR}$. This could lead to a progressive reduction in the surface expression and activity of glandular $\mathrm{M}_{3} \mathrm{mAChR}$, resulting in xerostomy, xerophthalmia and other general and dysautonomic parasympathetic symptoms in SS patients.

\section{Influence of Anti-M mACHR IgG on Submandibular Gland on the Activation and Expression of Nitric Oxide Syntase}

\section{Methods}

Ethical approval of the study protocol: The study protocol complied with the tenets of the Declaration of Helsinki and accomplished with the rules established by the Ethics Committee of the University of Buenos Aires (Buenos Aires, Argentina). All subjects provided written informed consent.

Drugs: A 25-mer peptide (K-R-T-V-P-D-N-Q-C-F-I-Q-F-L-SN-P-A-V-T-F-G-T-A-I) corresponding to the sequence of the second extracellular loop of the human $\mathrm{M}_{3} \mathrm{mAChR}$ was synthesized by Peptido Genetic Research Company (Livermore, CA, USA) as previously described [72]. Atropine, verapamil and trifluoroperazine (TFP) were obtained from Sigma-Aldrich (St. Louis, MO, USA); J104129, ODQ, U-73122, S-Methylisothioures (S-Methy-U), L-NIO dehydrochloride (L-NIO), N-Propyl-L-arginine hydrochloride (N-PL) and L-NGmonomethyl arginine citrate (L-NMMA) were from Tocris Cookson (Ellisville, MO, USA). Stock solutions were freshly prepared in the appropriate buffers. The drugs were diluted in a water bath to achieve the final concentrations stated in the text.

Patients: The subjects of this study were 30 pSS patients' anti-Ro/ SSA positive and 30 healthy volunteers all female, (age 39-54 years) selected from the metropolitan area of Buenos Aires. The diagnosis of pSS fulfilled the criteria described by Vitali et al. [34] and was given by means of a positive biopsy with a score focus of $3.8 \pm 0.07$.

Purification of Human IgG: The serum IgG fraction from patients with pSS and from normal individuals (control) was isolated using protein $\mathrm{G}$ affinity chromatography as described elsewhere [41]. Briefly, sera were loaded onto the protein $\mathrm{G}$ affinity column (Sigma-Aldrich, St Louis, MO, USA) equilibrated with 1 MTris- $\mathrm{HCl}(\mathrm{pH} 8.0)$ and the columns were washed with 10 volumes of the same buffer. The IgG fraction was eluted with $100 \mathrm{mM}$ glycine- $\mathrm{HCl}, \mathrm{pH} 3.0$, and immediately neutralized. The concentration and purification of IgG were determined using a radial immune diffusion assay.

Anti- $M_{3}$ peptide IgG procedure: The IgG fraction from 30 patients with pSS and 30 healthy subjects was independently subjected to affinity chromatography on the synthesized peptide covalently linked to AffiGel 15 gel (Bio-Rad, Richmond, CA, USA) as described by Reina et al. [49]. Briefly, the IgG fraction was loaded onto the affinity column equilibrated with phosphate buffered saline (PBS). The non-peptide fraction was first eluted with the same buffer. Specific anti-peptide antibodies were then eluted with $3 \mathrm{M} \mathrm{KSCN}$ and $1 \mathrm{M} \mathrm{NaCl}$, followed by immediate extensive dialysis against PBS.

The IgG concentration of non-anti-peptide antibodies and specific anti-muscarinic receptor peptide antibodies was determined by a radial immunodiffusion assay. Their immunological reactivity against muscarinic receptor peptides was evaluated by ELISA. The concentration of the affinity-purified anti- $\mathrm{M}_{3}$ peptide $\operatorname{IgG}\left(1 \times 10^{-8} \mathrm{M}\right)$ increased optical density (mean OD \pm SEM, $2.4 \pm 0.2$ ). 
The non-anti- $\mathrm{M}_{3}$ peptide IgG fraction eluted from the column showed OD values $(0.27 \pm 0.06)$ similar to those of normal $\mathrm{IgG}$ from healthy individuals taken as control $(0.26 \pm 0.05)$. The normal IgG fraction purified by affinity column chromatography gave a negative result $(0.30 \pm 0.03)$. ELISA was performed as described previously [74]

ELISA: Fifty microliters of $M_{3}$ synthetic peptide solution $(20 \mu \mathrm{g} /$ $\mathrm{ml}$ ) in $0.1 \mathrm{M} \mathrm{Na}_{2} \mathrm{CO}_{3}$ buffer, $\mathrm{pH} 9.6$, was used to coat microtiter plates (NUNC, Kastrup, Denmark) at $4^{\circ} \mathrm{C}$ overnight. After blocking the wells, diluted sera from pSS patients and healthy individuals were added in triplicate and allowed to react with the peptide for 2 hour at $37^{\circ} \mathrm{C}$.

After the wells were thoroughly washed with $0.05 \%$ Tween 20 in a PBS, $100 \mu \mathrm{l}$ of 1:6000 biotinylated goat anti-human IgG antibodies (Sigma Chemical Co., St. Louis, MO, USA) was added and incubated for 1 hour at $37^{\circ} \mathrm{C}$. Then, a 1:6000 dilution of extravidin-alkaline phosphatase (Sigma) was allowed to react an extra $30 \mathrm{~min}$ at $37^{\circ} \mathrm{C}$. After extensive washings, p-nitrophenylphosphate $(1 \mathrm{mg} / \mathrm{ml})$ was added as the substrate, and the reaction was stopped at $30 \mathrm{~min}$. Finally, the plates were read at $405 \mathrm{~nm}$ and the results for each sample were expressed as the means \pm SD of triplicate values.

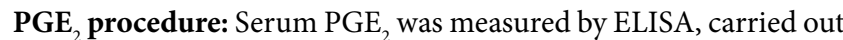
according to the manufacturer's protocols (Biotrack Enzyme Immune Assay System, Amersham Bioscience, Piscateway, NJ, USA).

The OD cutoff value of $\mathrm{PGE}_{2}$ was $4.4 \pm 0.33 \mathrm{ng} / \mathrm{ml}$. All serum samples were frozen promptly after collection and kept at $-80^{\circ} \mathrm{C}$ until used for $\mathrm{PGE}_{2}$ determination. The result is expressed as $\mathrm{ng} / \mathrm{ml}$.

Nitric oxide synthase (NOS) assay: NOS activity was measured in rat submandibular gland tissue by production of $\left[\mathrm{U}-{ }^{14} \mathrm{C}\right]$-citrulline from [U-14C]-arginine according to the procedure described for brain slices [77]. Briefly, after 20-min preincubation in KRB solution, tissues were transferred to $500 \mathrm{ml}$ of prewarmed $\mathrm{KRB}$ equilibrated with $5 \%$ $\mathrm{CO}_{2}$ in $\mathrm{O}_{2}$ in the presence of [U-14C]-arginine $(0.5 \mathrm{mCi})$.

Drugs were added and the mixture incubated for 20 min under $5 \% \mathrm{CO} 2$ in $\mathrm{O} 2$ at $37^{\circ} \mathrm{C}$. Tissues were then homogenized with an Ultraturrax homogenizer in $1 \mathrm{ml}$ of medium containing $20 \mathrm{mM}$ HEPES (pH 7.4), $0.5 \mathrm{mM}$ ethyleneglycol tetra-acetic acid (EGTA), $0.5 \mathrm{mM}$ ethylenediamine tetra-acetic acid (EDTA), $1 \mathrm{mM}$ dithiothreitol, $1 \mathrm{mM}$ leupeptin and $0.2 \mathrm{mM}$ phenylmethylsulphonyl fluoride (PMSF) at $4^{\circ} \mathrm{C}$.

After centrifugation at $20,000 \times \mathrm{g}$ for $10 \mathrm{~min}$ at $4^{\circ} \mathrm{C}$, supernatants were applied to $2 \mathrm{ml}$ columns of Dowex AG $50 \mathrm{WX}-8$ (sodium form). [14C]-citrulline was eluted with $3 \mathrm{ml}$ of water and quantified by liquid scintillation counting. The results were expressed as picomol per gram tissue wet weight ( $\mathrm{pmol} / \mathrm{g} / \mathrm{tissue}$ wet $\mathrm{wt})$.

Cyclic nucleotides assay (cGMP): Rat submandibular gland (10 $\mathrm{mg}$ ) was incubated in $1 \mathrm{ml}$ Krebs Ringer Buffer (KRB) for $30 \mathrm{~min}$, and the anti- $\mathrm{M}_{3} \mathrm{mAChR}$ peptide IgG was added in the last $15 \mathrm{~min}$. When a blocker was used, it was added $25 \mathrm{~min}$ before the addition of the antibody. After incubation, submandibular gland tissue was homogenized in $2 \mathrm{~mL}$ of absolute ethanol and centrifuged $\left(6000 \times \mathrm{g}, 15 \mathrm{~min}, 4^{\circ} \mathrm{C}\right)$.
Pellets were then re-homogenized in ethanol-water (2:1) and recentrifuged. The supernatant was collected and evaporated to dryness. Cyclic GMP in the residue was dissolved in $400 \mu \mathrm{l}$ of $0.05 \mathrm{M}$ sodium acetate buffer ( $\mathrm{pH}$ 6.2). For the determination of nucleotide, we used ELISA employing the protocol for the production of cGMP from Amersham Biosciences (Piscataway, NJ, USA). Results are expressed as picomoles per milligram of wet weight of tissue ( $\mathrm{pmol} / \mathrm{mg}$ tissue wet weight).

mRNA isolation and cDNA synthesis: Total RNA was extracted from rat submandibular gland slices by homogenization using guanidiniumisothiocyanate method. As previously described [41], a $20-\mu \mathrm{l}$ reaction mixture contained 2 ng of mRNA, 20 units of RNase inhibitor, $1 \mathrm{mMdNTPs}$ and 50 units of Moloney murine leukemia virus reverse transcriptase (Promega, Madison, WI, USA). First-strand cDNA was synthesized at $37^{\circ} \mathrm{C}$ for $60 \mathrm{~min}$.

PCR procedures: NOS isoform-mRNA levels were determined by a method that involves simultaneous co-amplification of both the target cDNA and a reference template (MIMIC) with a single set of primers. MIMIC for eNOS, nNOS and glyceraldehyde-3-phosphate dehydrogenase $\left(\mathrm{G}_{3} \mathrm{PDH}\right)$ was constructed using a PCR MIMIC construction kit (Clontech Laboratories, Palo Alto, CA).

Each PCR MIMIC consists of a heterologous DNA fragment with 5' and 3'-end sequences that recognized by a pair of gene-specific primers. Sizes of PCR MIMIC were distinct from those of native targets. The sequence of oligonucleotideprimer pairs used for construction of MIMIC and amplification of NOS isoforms and G3PDH mRNA is listed in Table 1.

Aliquots were taken from pooled first-strand cDNA from the same group and constituted one sample for PCR. A series of 10 -fold dilutions of known concentrations of the MIMIC were added to PCR amplification reactions containing the first-strand CDNA. PCR MIMIC amplification was performed in $100 \mu \mathrm{l}$ of a solution containing $1.5 \mathrm{mM} \mathrm{MgCl}, 0.4$ $\mu \mathrm{M}$ primer, dNTPs, $2.5 \mathrm{U}$ Taq DNA polymerase and $0.056 \mu \mathrm{MTaq}$ Start antibody (Clontech Laboratories). After initial denaturation at $94^{\circ} \mathrm{C}$ for $2 \mathrm{~min}$, the cycle condition was $30 \mathrm{~s}$ of denaturation at $94^{\circ} \mathrm{C}, 30 \mathrm{~s}$ of annealing at $60^{\circ} \mathrm{C}$ and $45 \mathrm{~s}$ for enzymatic primer extension at $72^{\circ} \mathrm{C}$ for 45 cycles for NOS isoforms. The internal control was the mRNA of the housekeeping gene glyceraldehyde-3-phosphate dehydrogenase $\left(\mathrm{G}_{3} \mathrm{PDH}\right)$.

PCR amplification was performed with initial denaturation at $94^{\circ} \mathrm{C}$ for 2 min followed by 30 cycles of amplification. Each cycle consisted of $35 \mathrm{~s}$ at $94^{\circ} \mathrm{C}, 35 \mathrm{~s}$ at $58^{\circ} \mathrm{C}$ and $45 \mathrm{~s}$ at $72^{\circ} \mathrm{C}$. Samples were incubated for an additional $8 \mathrm{~min}$ at $72^{\circ} \mathrm{C}$ before completion. PCR products were subjected to electrophoresis on ethidium bromide-stained gels. Band intensity was quantitated by densitometry using NIH Image software. Levels of mRNA were calculated from the point of equal density of the sample and MIMIC PCR products [41].

NOS isoforms mRNA levels were normalized with the levels of $\mathrm{G}_{3} \mathrm{PDH}$ mRNA present in each sample, which served to control for

\begin{tabular}{|c|c|c|c|}
\hline Gene Product & Sense & Antisense & Predicted size (bp) \\
\hline iNOS & 5' GAT CAA TAACCT GAA GCC CG 3' & 5' GCC CTT TTT TGC TCC ATA GG 3' & 578 \\
\hline nNOS & 5' GCGGA GCAGA GCGGC CTTAT 3' & 5' TTTGGT GGGAG GACCG AGGG 3' & 240 \\
\hline eNOS & 5' CCGCA CTTCT GTGCC TTTGC TC3' & 5'GCTCG GGTGG ATTTGC TGCTCT 3' & 360 \\
\hline$g_{3} p d h$ & $5^{\prime}$ ACCAC AGTCCA TGCCAT CAC $3^{\prime}$ & 5' TCCAC CACCC TGTTG CTGTA 3' & 452 \\
\hline
\end{tabular}

Table 1: Oligonucleotides of primers for PCR. 
Citation: Reina S, Borda E (2014) Autoantibodies against Muscarinic Acetylcholine Receptor on Exocrine Glands in Sjögren Syndrome. Dentistry 4: 265. doi:10.4172/2161-1122.1000265

variations in RNA purification and cDNA synthesis. Relative mRNA expression of nNOS and eNOS were compared with those from the respective normal individuals and pSS patients reported as a percentage of normal.

Statistical analyses: The Student's " $t$ " test for unpaired values was used to determine the level of significance. If multiple comparisons were necessary, after analysis of variance, the Student-Newman-Keuls test was applied. Differences between means were considered significant if $\mathrm{P}<0.05$.

\section{Results}

Figure 1 shows the immunoreactivity of sera (A), pSSIgG (B) and pSSIgG anti $M_{3} m A C h R$ synthetic peptide (pSSIgG anti $M_{3}$ ) (C) of pSS patients and healthy individuals against $M_{3}$ synthetic peptide.
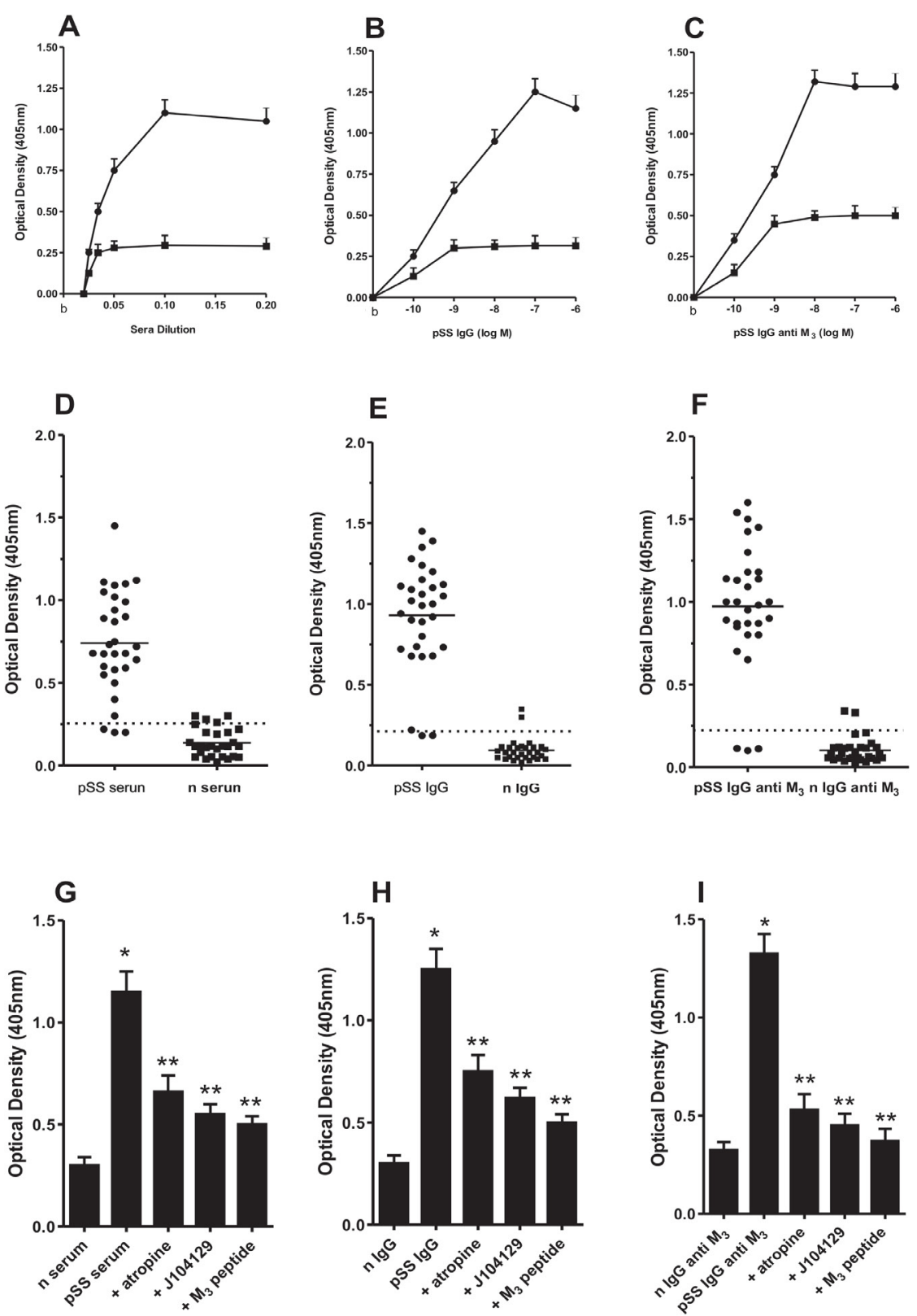

Figure 1: Effect of serum, IgG and IgG anti $M_{3}$ autoantibodies from patients with primary Sjögren syndrome (pSS) evaluated by enzyme immunoassay (ELISA). UPPER PANEL: Dose-response curve of different serum dilution (A), different concentration of pSS $\operatorname{lgG}(B)$ and different concentration of pSS IgG anti $M_{3}(C)$ autoantibodies of pSS patients $(\bullet)$ against $\mathrm{M}_{3} \mathrm{mAChR}$ synthetic peptide. The values of normal sera and normal IgG and normal IgG anti $\mathrm{M}_{3}(\boldsymbol{\bullet})$ is also shown. ${ }^{*} \mathrm{P}<0.0001$ versus serum, $\mathrm{IgG}$ and IgG anti $\mathrm{M}_{3}$ of normal individuals. MIDDLE PANEL: Scatterogram showing immunoreactivity of pSS serum (D), pSS IgG (E) and pSS IgG anti $M_{3}(F)$ of $S S$ patients $(\bullet)$ and normal individuals ( $\bullet$ ) against $M_{3}$ synthetic peptide. The individual optical density (OD) values for each serum sample or pSS IgG or pSS IgG anti $M_{3}$ were taken from 30 normal individuals and 30 patients with pSS. OD values more than 2 SD above the normal mean, were taken as positive. Cut off value of OD: $D=$ $0.25 \pm 0.05, E=0.24 \pm 0.06$ and $\mathrm{F}=0.18 \pm 0.03$ respectively. LOWER PANEL: Influence of $1 \times 10^{-6} \mathrm{M}$ atropine (unspecific mAChR antagonist), $1 \times 10^{-8} \mathrm{M} J 104129$ (specific $\mathrm{M}_{3} \mathrm{mAChR}$ antagonist) and $5 \times 10^{-7} \mathrm{M}$ anti $\mathrm{M}_{3}$ synthetic peptide on the maximal dilution or concentration of serum $(G)$, pSS IgG (H) and pSS IgG anti $\mathrm{M}_{3}(\mathrm{I})$ respectively. The values of normal sera and normal lgG and normal lgG anti $\mathrm{M}_{3}$ is also shown. Values are mean \pm SEM from a pool of 30 pSS patients and 30 normal individuals. ${ }^{*} \mathrm{P}<0.0001$ versus normal $(\mathrm{n})$ serum or IgG; ${ }^{*} \mathrm{P}<0.001$ versus $\mathrm{pSS}$ serum or $\mathrm{pSS}$ IgG. All the experiments were performed by duplicates. 
Citation: Reina S, Borda E (2014) Autoantibodies against Muscarinic Acetylcholine Receptor on Exocrine Glands in Sjögren Syndrome. Dentistry 4: 265. doi:10.4172/2161-1122.1000265

We can see that the optical density values (OD) of pSSIgG anti $M_{3}$ was significantly higher than those of pSSIgG and pSS serum. Serum, IgG and pSSIgG anti $\mathrm{M}_{3}$ of healthy individuals showed similar OD values, which are significantly lower than those of SS patients.

Scatterogram (Figure 1) shows the immunoreactivity of pSS serum (D), pSSIgG (E) and pSSIgG anti $\mathrm{M}_{3}(\mathrm{~F})$ of pSS patients and normal individuals against $\mathrm{M}_{3}$ synthetic peptide. The immunoreactivity of serum, pSSIgG and pSSIgG anti $\mathrm{M}_{3}$ was significantly $(\mathrm{P}<0.0001)$ higher than that of normal individuals used as control.The specificity of the reaction was assessed by the ability of the $M_{3}$ synthetic peptide, atropine (unspecific muscarinic antagonist) and $\mathrm{J} 104129$ (specific $\mathrm{M}_{3}$ muscarinic antagonist) to inhibit the reaction when serum or IgG was incubated with salivary gland membrane mAChR (Figure 1G-I).

Figure $2 \mathrm{~A}$ shows the ability of pSSIgG anti M3 to stimulate NOS

A

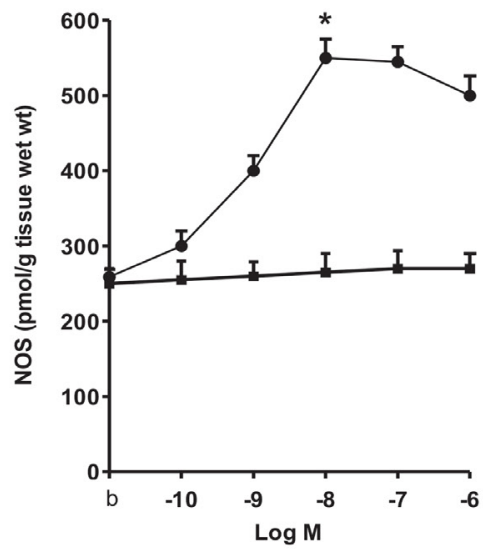

activity in a concentration-dependent manner. L-NMMA $5 \times 10^{-5} \mathrm{M}$ blocked the action of pSSIgG anti $\mathrm{M}_{3}$ on NOS activity. Figure 2B (black column) shows the maximal effect of $1 \times 10^{-8} \mathrm{M}$ of $\mathrm{pSSIgG}$ anti $\mathrm{M}_{3}$ alone (b) or in the presence of the $1 \times 10^{-5} \mathrm{M} \mathrm{L}-\mathrm{NMMA}$ (c) or L-NMMA plus $1 \times 10^{-4} \mathrm{M}$ L-arginine (d) (reverse experiment). Basal (control) values are also shown (a). The IgG anti $M_{3}$ of normal individuals (white column) used as a control, is shown (Figure $2 \mathrm{Ba}-\mathrm{d}$ ).

The particular NOS isoforms enzymes which participate in the generation of endogenous nitric oxide (NO), can be seen in Figure 3 . The specific inhibition of iNOS with S-Methylisothioures (S-Methy-U) prevented the stimulation of NOS activity by the pSSIgG anti $\mathrm{M}_{3}$. The inhibition of eNOS by L-NIO dehydrochloride (L-NIO) and nNOS by $\mathrm{N}$-Propyl-L-arginine hydrochloride (N-PL) were without any effect being iNOS the only isoform able to impair the stimulation of NOS activity by the autoantibody. The table inserted in this figure, shows the
B

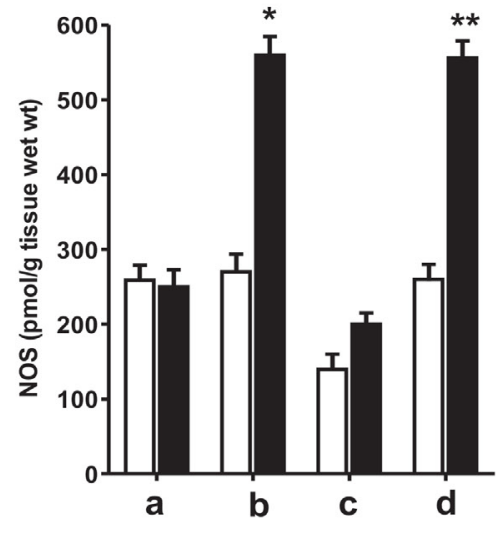

Figure 2: A: Concentration-response curve of pSS $\lg$ anti $M 3(\bullet)$ and normal $\operatorname{lgG}$ anti $M_{3}(\bullet)$ on nitric oxide synthase (NOS) activity from rat submandibular gland Basal value (b) corresponds to NOS activity after $60 \mathrm{~min}$ of incubation [254 $\pm 19 \mathrm{pmol} / \mathrm{g}$ tissue wet wt]. Values are mean \pm SEM of five experiments in each group performed in duplicate. ${ }^{*} \mathrm{P}<0.0001$ versus $5 \times 10^{-5} \mathrm{M}$ L-NMMA + pSS IgG anti $\mathrm{M}_{3}$. B: Preparations [white columns: normal lgG anti $\mathrm{M}_{3}$ ( $\mathrm{n}$ IgG anti $\mathrm{M} 3$ ) and black columns pSS IgG anti M3] were incubated for 60 min with $1 \times 10^{-8} \mathrm{M}$ pSS IgG anti $\mathrm{M}_{3}$ in absence (b) or in presence (c) of $5 \times 10^{-5} \mathrm{M} \mathrm{L-NMMA}$ and L-NMMA plus $1 \times 10^{-4} \mathrm{M} \mathrm{L}^{2}-\mathrm{arginine}$ (d). Basal values before the addition of any antibody or drugs (a). Values are mean \pm SEM of five experiments in each group performed in duplicate. ${ }^{*} P<0.0001$ versus n IgG anti $M_{3},{ }^{* *} \mathrm{P}<0.001$ versus nlgG anti $\mathrm{M}_{3}$.

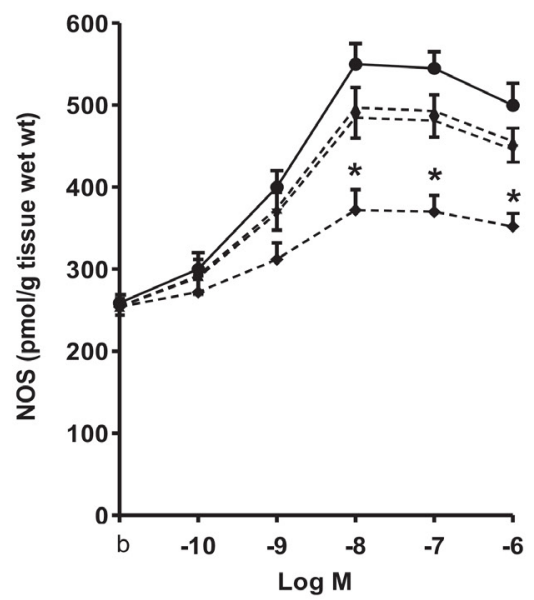

NOS activity in the presence of nlgG anti $\mathrm{M}_{3}$. Influence of different isoforms inhibitors

\begin{tabular}{|c|c|c|c|c|c|}
\hline \multirow{2}{*}{ Additions } & \multicolumn{5}{|c|}{$\mathrm{nIgG}$ anti $\mathrm{M}_{3}$} \\
\hline & $1 \times 10^{-10} \mathrm{M}$ & $1 \times 10^{-9} \mathrm{M}$ & $1 \times 10^{-8} \mathrm{M}$ & $1 \times 10^{-7} \mathrm{M}$ & $1 \times 10^{-6} \mathrm{M}$ \\
\hline None & $255.2 \pm 19$ & $260.4 \pm 20$ & $265.2 \pm 18$ & $270.1 \pm 19$ & $270.2 \pm 18$ \\
\hline $\begin{array}{c}+ \text { N-PL } \\
\left(5 \times 10^{-6} M\right)\end{array}$ & $255.2 \pm 20$ & $255.8 \pm 19$ & $257.3 \pm 15$ & $258.8 \pm 16$ & $258.8 \pm 15$ \\
\hline $\begin{array}{c}+\mathrm{L}-\mathrm{NIO} \\
\left(5 \times 10^{-6} \mathrm{M}\right)\end{array}$ & $255.6 \pm 16$ & $258.6 \pm 16$ & $262.1 \pm 16$ & $265.8 \pm 16$ & $265.8 \pm 14$ \\
\hline $\begin{array}{l}+ \text { S-Methyl-U } \\
\quad\left(1 \times 10^{-5} \mathrm{M}\right)\end{array}$ & $255.8 \pm 18$ & $259.7 \pm 15$ & $264.5 \pm 14$ & $269.4 \pm 14$ & $269.4 \pm 15$ \\
\hline
\end{tabular}

Values are mean $\pm \mathrm{SEM}$ of five experiments in each case performed by duplicate.

Figure 3: Upper panel: Effect of pSS IgG anti $\mathrm{M}_{3}$ on NOS activity in salivary gland. Submandibular gland were incubated with increasing concentrations of pSS IgG anti $\mathrm{M}_{3}$ alone $(\bullet)$ or in the presence of $1 \times 10^{-5} \mathrm{M}(\mathrm{S})$ Methylisothioures (S-Methy-U) $(\bullet), 5 \times 10^{-6} \mathrm{M}$ L-NIO dehydrochloride (L-NIO) $(\boldsymbol{\Delta})$ or $5 \times 10^{-6} \mathrm{M} \mathrm{N}-\mathrm{Propyl}-\mathrm{L}-\mathrm{arginine}$ hydrochloride $(\mathrm{N}-\mathrm{PL})(\boldsymbol{\nabla})$. ${ }^{*} \mathrm{P}<0.0001$ versus pSS IgG anti $\mathrm{M}_{3}$. Values are mean \pm SEM of five experiments performed in duplicate. Lower panel: Table insert in Figure showed the effect of normal $\operatorname{lgG}$ anti $\mathrm{M}_{3}\left(n \mathrm{IgG}\right.$ anti $\mathrm{M}_{3}$ ) alone or in the presence of different NOS isoforms inhibitors taken as control values. 
Citation: Reina S, Borda E (2014) Autoantibodies against Muscarinic Acetylcholine Receptor on Exocrine Glands in Sjögren Syndrome. Dentistry 4: 265. doi:10.4172/2161-1122.1000265

values of NOS activity in the presence of normal IgG anti $\mathrm{M}_{3}$ and the isoforms inhibitors taken as a control. These results indicate that the pSSIgG anti $\mathrm{M}_{3}$ stimulated NOS activity is a result of the increment in NO with major participation of iNOS.

In order to discern, which endogenous mechanisms (second messengers) are implicated in pSSIgG anti $\mathrm{M}_{3}$ NOS activation and the generation of NO production, several inhibitors of this enzymatic pathways were used. It can be seen in Figure 4 that the stimulation of NOS activity by the pSSIgG anti $\mathrm{M}_{3}$ was inhibited by $\mathrm{M}_{3}$ synthetic peptide (A, B, C), S-Methyl-U and U-73122 (A), L-NIO and verapamil
(B) and N-PL and TFP (C). These results indicate that pSSIgG anti $\mathrm{M}_{3}$ $\mathrm{M}_{3} \mathrm{mAChR}$ stimulation may trigger the production of NO synthesis in submandibular salivary glands by iNOS isoforms dependent on PLC activation. NO exerts its effects mainly by activating soluble guanylyl cyclases in the presence of the pSSIgG anti $\mathrm{M}_{3}$ in a concentration dependent manner, increasing cGMP synthesis in rat submandibular gland (Figure 5).

The increment in cGMP production is inhibited by the specific soluble guanylylcyclases inhibitor (ODQ) and the IgG anti $M_{3}$ of normal individuals was without effect in our system (A). The NO-
A

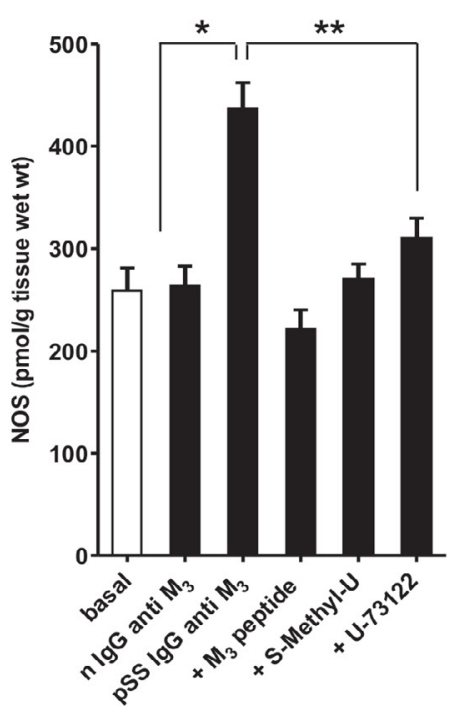

B

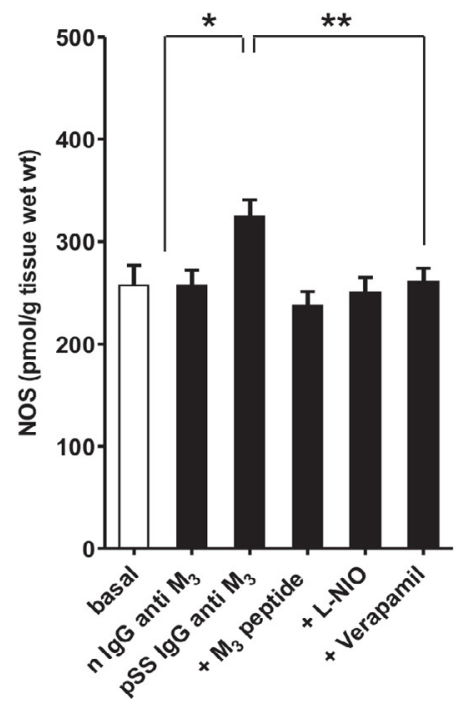

C

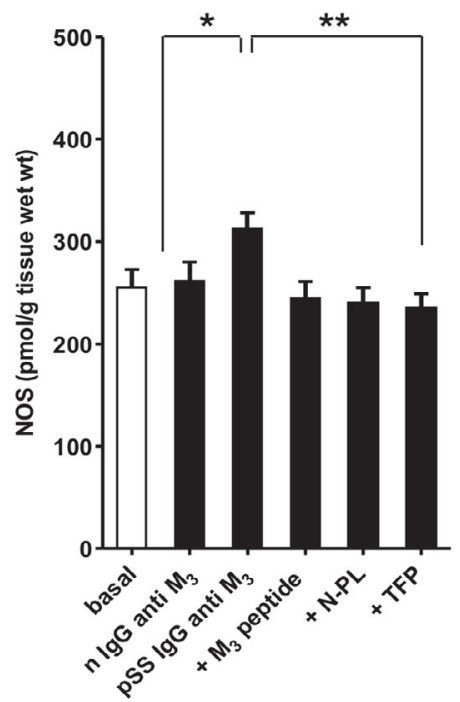

Figure 4: Effect of pSS IgG anti M3 (black column) on NOS activity in submandibular gland. The glands were incubated with $1 \times 10^{-8} \mathrm{M}$ pSS IgG anti M3 alone or in the presence of $1 \times 10^{-4} \mathrm{M}$ synthetic $\mathrm{M}_{3}$ peptide, $1 \times 10^{-5} \mathrm{M}$ S-Methyl-U and $5 \times 10^{-6} \mathrm{M} \mathrm{U}-73122(\mathrm{~A}), 1 \times 10^{-4} \mathrm{M}$ synthetic M3 peptide, $5 \times 10^{-6} \mathrm{M}$ L-NIO and $5 \times 10^{-5} \mathrm{M}$ verapamil (B) and $1 \times 10^{-4} \mathrm{M}$ synthetic $\mathrm{M} 3$ peptide, $5 \times 10^{-6} \mathrm{M} \mathrm{N}-\mathrm{PL}$ and $5 \times 10^{-6} \mathrm{M}$ TFP $\left(\mathrm{C}\right.$ ). Basal values (white column) without any additions and $\mathrm{n}$ IgG anti $\mathrm{M}_{3}$ were also shown. Values are mean \pm SEM of six experiments performed in duplicate. ${ }^{*} P<0.001$ versus basal and $n \lg$ anti $M_{3},{ }^{* *} P<0.001$ versus $p S S$ IgG anti $M_{3}$ alone.

A

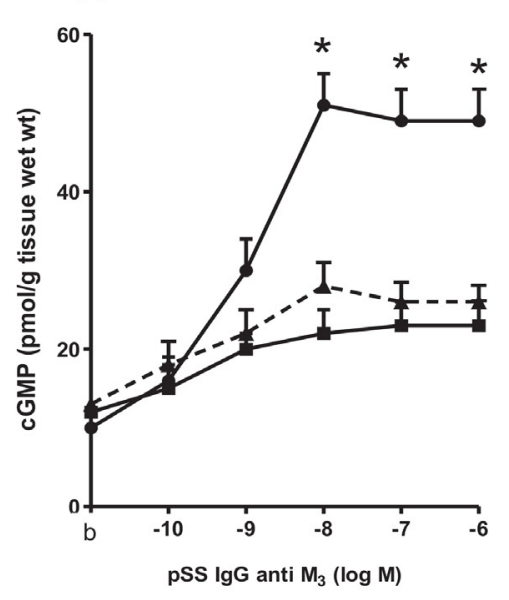

B

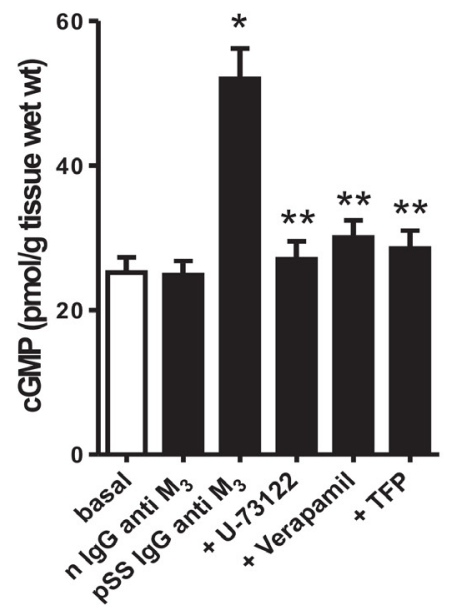

Figure 5: Effects of pSS IgG anti $M_{3}$ in salivary glands. (A) Submandibular glands were incubated with increasing concentration of pSS IgG anti $M_{3}$ alone ( $\bullet$ ) or in the presence of ODQ $\left(1 \times 10^{-7} \mathrm{M}\right)(\boldsymbol{\Delta})$ and $n \lg G$ anti $M_{3}(\mathbf{m})$. Values represent the mean \pm SEM of five experiments performed in duplicate. ${ }^{*} P>0.0001$ versus $p S S$ IgG anti $\mathrm{M}_{3}+$ ODQ. (B) Action of pSS IgG anti $\mathrm{M}_{3}$ on cyclic GMP (cGMP) accumulation rat submandibular gland were incubated with $1 \times 10^{-8} \mathrm{M}$ of pSS IgG anti $\mathrm{M}_{3}$ alone or in the presence of different inhibitors: U-73122 at $5 \times 10^{-6} \mathrm{M}$, verapamil at $5 \times 10^{-5} \mathrm{M}$ and TFP at $5 \times 10^{-6} \mathrm{M}$. Results are mean \pm SEM of four experiments performed in duplicate in each groups. ${ }^{*} P<0.0001$ versus basal and $n \lg G$ anti $M_{3}$, ${ }^{* *} P<0.001$ versus $p S S \lg G$ anti $M_{3}$. 
cGMP accumulation is mediated by the effect of PLC, calcium influx and calcium/calmodulin activation (B) since the NO-cGMP increment is blunted by U-73122, verapamil and TFP. To settle the role of NOS isoforms in the action of PSSIgG anti $\mathrm{M}_{3}$ on rat submandibular gland $\mathrm{M}_{3} \mathrm{mAChR}$ activation, specific primers for iNOS (A), nNOS (B) and eNOS (C) were used.

Figure 6 shows RT-PCR products and semi-quantitative RT-PCR analysis demonstrating that the $\mathrm{pSSIgG}$ anti $\mathrm{M}_{3} 1 \times 10^{-8} \mathrm{M}$ stimulation for one hour increase NOS mRNA levels with no modification of NOS mRNA levels by normal IgG anti $M_{3}$ (control). The same figure shows that $\mathrm{M}_{3}$ synthetic peptide, S-Methil-U, L-NIO and N-PL attenuate the stimulatory effect of pSSIgG anti $\mathrm{M}_{3}$ on NOS mRNA levels. The internal control for the mRNA of the housekeeping gene of glyceraldehyde3-phosphate- dehydrogenase ( $\mathrm{g}_{3} \mathrm{pdh}$ ) is shown. Regarding mRNA expression these results demonstrate that PSSIgG anti $\mathrm{M}_{3}$ acts as an inducer of iNOS mRNA without a significative action on $\mathrm{nNOS}$ and eNOS mRNA levels.

The sequence of oligonucleotide primers pairs used is listed in Table 1. The relative mRNA expression of iNOS, nNOS and eNOS in each group was compared to those of the corresponding normal group and reported as a percentage.

The fact that pSSIgG anti $\mathrm{M}_{3}$ antibody induces iNOS activity and expression, tempts us to speculate that the antibody can have direct influence on rat submandibular gland through the production of a large amount of pro-inflammatory substances and cytotoxic NO by means of the activation of mAChR subtype $\mathrm{M}_{3}$. In turn, NO could be said to contribute to immune inflammation at the level of rat submandibular gland, regulating not only the degree of inflammation but also decreasing salivary secretion. All of these facts are the consequence of an abnormal glandular parasympathetic function (parasympathetic dysautonomia) with the participation of PLC $\left(\mathrm{IP}_{3}\right)$, calcium influx and calcium/calmodulin activation.

\section{Conclusion}

The present study suggests a complex interplay between different factors involved in innate and adaptive immunity. The presence of anti-M $\mathrm{M}_{3} \mathrm{mAChR}$ peptide IgG and the enhancement of NOS activity and its expression could provide a link between autoimmunity and parasympathetic system in Sjögren syndrome. Further, the early agonist-promoting activation of salivary gland $\mathrm{M}_{3} \mathrm{mAChR}$ initiated by cholinergic autoantibodies binds to and persistently activates cholinoceptors, resulting in the production of large amounts of proinflammatory substances, contributing to inflammation.

The cholinergic agonistic activity displayed by anti- $\mathrm{M}_{3} \mathrm{mAChR}$ peptide IgG could subsequently induce desensitisation, internalisation and/or intracellular degradation of glandular $\mathrm{M}_{3} \mathrm{mAChR}$. This would lead to a progressive reduction in the surface expression and activity of glandular $\mathrm{M}_{3} \mathrm{mAChR}$, resulting in xerostomy, xerophthalmia and other general parasympathetic symptoms in SS patients.

In this paper we propose a model to explain the mechanism whereby $\mathrm{pSSIgG}$ stimulate rat submandibular gland $\mathrm{mAChR}$ subtype $\mathrm{M}_{1}$ and $\mathrm{M}_{3}$. According to our model pSSIgG acting on frontal cerebral cortex and submandibular gland $m A C h R$ subtype $M_{1}$ and $M_{3}$ activate the $G \beta \gamma$ subunit protein.

The activation of G $\beta \gamma$ leads to the activation of caspase- 8 and the Gas/q subunit provoking JNK phosphorylation and increasing MMP-3 production, which contributes to increase PGE levels. Gas/q subunit itself also activates PLC with the production of $\mathrm{IP}_{3}$ (that in turn increase intracellular calcium concentration) and DAG (that in turn activating PKC activity) and provokes the decrement of the salivary mucin leading to the reduction in the protection of the oral tissues.

Activation of adenylatecyclase leads to cAMP accumulation with an increase in the efflux of extracellular calcium. This, in turn, increases intracellular calcium concentrations; and induces their binding to the calcium/calmodulin complex (CaM). The CaM complex increases nitric oxide synthase activity through the inducible isoform (iNOS) that, in turn, increases Nitric Oxide (NO) production, triggering cyclic GMP (cGMP) accumulation.

The overproduction of $\mathrm{NO}$ also triggers the induction of iNOS
A

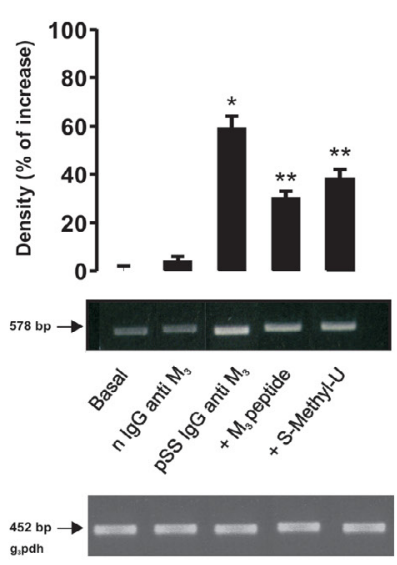

B

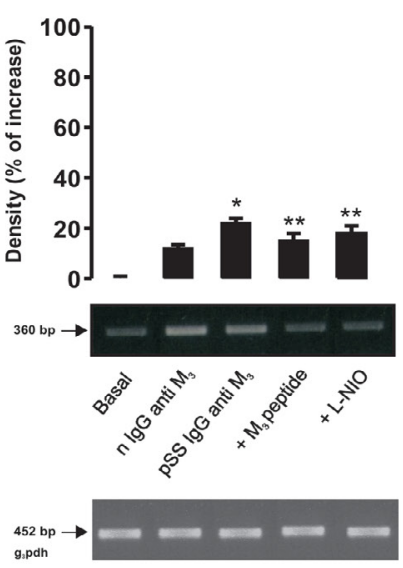

C

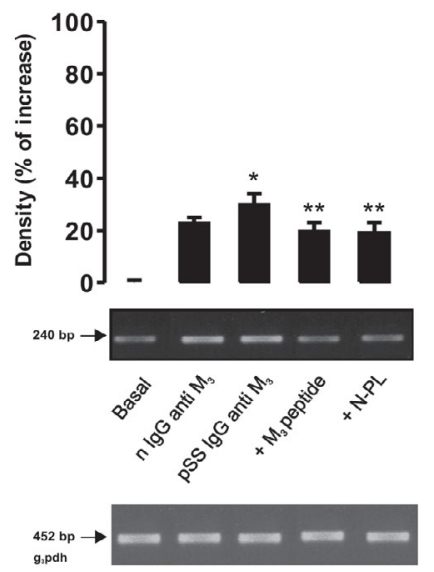

Figure 6: Action of pSS IgG anti $M_{3}$ on semi-quantitative RT-PCR analysis for iNOS (A), nNOS (B) and eNOS (C) mRNA levels from submandibular gland incubated during one hour with $1 \times 10^{-8} \mathrm{M}$ pSS IgG anti $\mathrm{M}_{3}$ in absence or in presence of $1 \times 10^{-4} \mathrm{M}$ synthetic $\mathrm{M}_{3}$ peptide and $1 \times 10^{-5} \mathrm{M} \mathrm{S-Methyl-U}(A)$ or $1 \times 10^{-4} \mathrm{M}$ synthetic $\mathrm{M}_{3}$ peptide and $5 \times 10^{-6} \mathrm{M} \mathrm{L-NIO}(\mathrm{B})$ or $1 \times 10^{-4} \mathrm{M}$ synthetic $\mathrm{M}_{3}$ peptide and $5 \times 10^{-6} \mathrm{M} \mathrm{N}-\mathrm{PL}(\mathrm{C})$. Basal value corresponds to mRNA level after one hour incubation without antibodies or drug inhibitors. Normal IgG anti $M_{3}\left(1 \times 10^{-8} \mathrm{M}\right)$ are also shown. The RT-PCR products obtained were: * $\mathrm{P}<0.0001$ versus nlgG anti $\mathrm{M} 3$ and basal and ${ }^{*} \mathrm{P}<0.001$ versus pSS IgG anti $M_{3}$. The internal control for the mRNA of the housekeeping gene of glyceraldehyde-3-phosphate-dehydrogenase ( $\left.g_{3} p d h\right)$ is shown. 
Citation: Reina S, Borda E (2014) Autoantibodies against Muscarinic Acetylcholine Receptor on Exocrine Glands in Sjögren Syndrome. Dentistry 4: 265. doi:10.4172/2161-1122.1000265

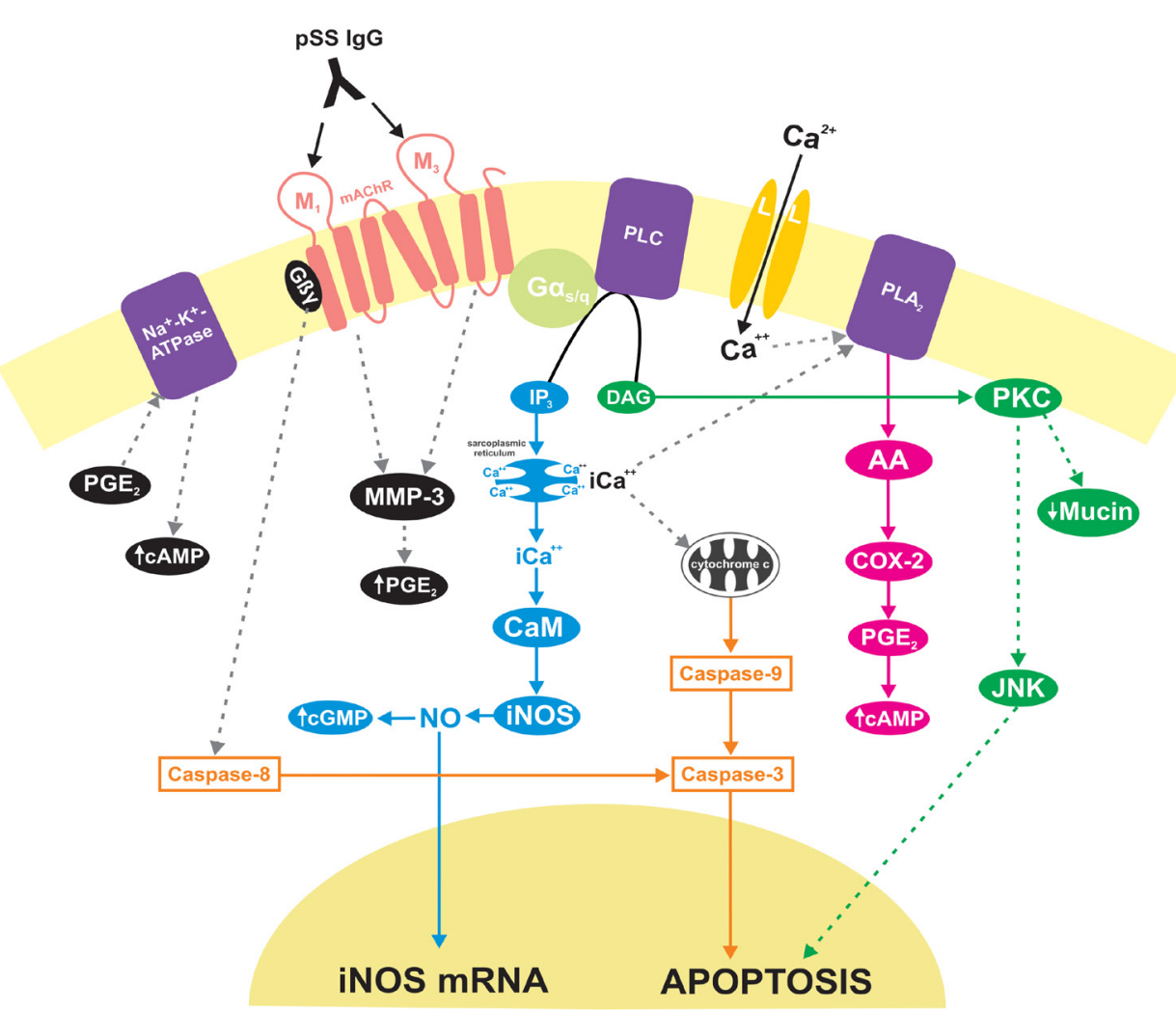

Figure 7: The previously related facts (findings and shadings) indicating direct mechanisms (filled arrows) and indirect mechanisms (dotted arrows).

mRNA levels. The rise in cytosolic calcium activates phospholipase $\mathrm{A}_{2}\left(\mathrm{PLA}_{2}\right)$ with activation of COX-2, which results in $\mathrm{PGE}_{2}$ generation with an increased production of cAMP levels. The generation of $\mathrm{PGE}_{2}$ induces the inhibition of membrane $\mathrm{Na}^{+}-\mathrm{K}^{+}$-ATPase activity accompanied by an increment of cAMP accumulation. The activation of caspases- 8 and -9 activates caspase- 3 , leading to apoptosis. Figure 7 below depicts the previously related facts (findings and shadings) indicates direct mechanisms (filled arrows) and indirect mechanisms (dotted arrows).

\section{Perspective}

The activation of glandular $\mathrm{M}_{3} \mathrm{mAChR}$ by the serum autoantibody present in patient with SS induces changes in the production of the second messengers. These changes are generated by the activation and binding of the glandular cholinoceptor. A synthetic $M_{3}$ peptide is able to block all actions generated by the antibody on glandular cholinoceptors. This being the case, the synthetic $\mathrm{M}_{3}$ peptide could be used as a therapeutic mean. Such a therapeutic mean, would capture the circulating $\mathrm{mAChR}$ autoantibodies thus reducing the destruction of the exocrine glands, the subsequent inflammatory process and indirectly the sicca symptoms of SS.

\section{Acknowledgment}

Supported by National Agency for Science and Technology (PICT 01647/ 02120), National Research Council of Argentina (CONICET) (PIP 11220110100019) and University of Buenos Aires (UBACyT 20020100100306).

\section{References}

1. Bacman S, Berra A, Sterin-Borda L, Borda E (2001) Muscarinic acetylcholine receptor antibodies as a new marker of dry eye Sjögren syndrome. Invest Ophthalmol Vis Sci 42: 321-327.
2. Berra A, Sterin-Borda L, Bacman S, Borda E (2002) Role of salivary IgA in the pathogenesis of Sjögren syndrome. Clin Immunol 104: 49-57.

3. Reina S, Sterin-Borda L, Orman B, Borda E (2004) Autoantibodies against cerebral muscarinic cholinoceptors in Sjögren syndrome: functional and pathological implications. J Neuroimmunol 150: 107-115.

4. Moutsopoulos HM (2014) Sjögren's syndrome: a forty-year scientific journey. J Autoimmun 51: 1-9.

5. Reina S, Sterin-Borda L, Borda E (2012) Anti-M(3) peptide IgG from Sjögren's syndrome triggers apoptosis in A253 cells. Cell Immunol 275: 33-41.

6. Fox I, Fox CM (2012) Sjögren's Syndrome. Publisher: Springer New York, Ed.: Fox, Fox. Sjögren's Syndrome: Practical Guidelines to Diagnosis and Therapy pp. 281-382.

7. Qin B, Wang J, Yang Z, Yang M, Ma N, et al. (2014) Epidemiology of primary Sjögren's syndrome: a systematic review and meta-analysis. annrheumdis-2014-2053-75.

8. Kramer JM (2014) Early events in Sjögren's Syndrome pathogenesis: the importance of innate immunity in disease initiation. Cytokine 67: 92-101.

9. Reina S, Passafaro D, Sterin-Borda L, Borda E (2012) Atorvastatin inhibits the inflammatory response caused by anti-M(3) peptide $\lg$ in patients with primary Sjögren's syndrome. Inflammopharmacology 20: 267-275.

10. Colburn KK, Green LM, Wong AK (2001) Circulating antibodies to guanosine in systemic lupus erythematosus: correlation with nephritis and polyserositis by acute and longitudinal analyses. Lupus 10: 410-417.

11. Orman B, Sterin-Borda L, De Couto Pita A, Reina S, Borda E (2007) Antibrain cholinergic auto antibodies from primary Sjögren syndrome sera modify simultaneously cerebral nitric oxide and prostaglandin biosynthesis. IntImmunopharmacol 7: 1535-1543.

12. Bohnhorst JØ, Bjørgan MB, Thoen JE, Natvig JB, Thompson KM (2001) Bm1 $\mathrm{Bm} 5$ classification of peripheral blood $B$ cells reveals circulating germinal center founder cells in healthy individuals and disturbance in the B cell subpopulations in patients with primary Sjögren's syndrome. Immunology 167: 3610-3618. 
Citation: Reina S, Borda E (2014) Autoantibodies against Muscarinic Acetylcholine Receptor on Exocrine Glands in Sjögren Syndrome. Dentistry 4: 265. doi:10.4172/2161-1122.1000265

13. Cruz-Tapias P, Rojas-Villarraga A, Maier-Moore S, Anaya JM (2012) HLA and Sjögren's syndrome susceptibility. A meta-analysis of worldwide studies. Autoimmun Rev 11: 281-287.

14. Peri Y, Agmon-Levin N, Theodor E, Shoenfeld $Y$ (2012) Sjögren's syndrome, the old and the new. Best Pract Res Clin Rheumatol 26: 105-117.

15. Gaston JS, Rowe M, Bacon P (1990) Sjögren's syndrome after infection by Epstein-Barr virus. J Rheumatol 17: 558-561.

16. Tzioufas AG, Tsonis J, Moutsopoulos HM (2008) Neuroendocrine dysfunction in Sjogren's syndrome. Neuroimmunomodulation 15: 37-45

17. Sumida T, Tsuboi H, lizuka M, Hirota T, Asashima H, et al. (2014) The role of M3 muscarinic acetylcholine receptor reactive T cells in Sjögren's syndrome: a critical review. J Autoimmun 51: 44-50.

18. Jonsson R, Vogelsang P, Volchenkov R, Espinosa A, Wahren-Herlenius M, et al. (2011) The complexity of Sjögren's syndrome: novel aspects on pathogenesis. Immunol Lett 141: 1-9.

19. Bikker A, Moret FM, Kruize AA, Bijlsma JW, Lafeber FP, et al. (2012) IL-7 drives Th1 and Th17 cytokine production in patients with primary SS despite an increase in CD4 T cells lacking the IL-7RÎ \pm . Rheumatology (Oxford) 51: 996-1005

20. Tengnér $P$, Halse AK, Haga HJ, Jonsson R, Wahren-Herlenius M (1998) Detection of anti-Ro/SSA and anti-La/SSB autoantibody-producing cells in salivary glands from patients with Sjögren's syndrome. Arthritis Rheum 41: 2238-2248.

21. Halse A, Harley JB, Kroneld U, Jonsson R (1999) Ro/SS-A-reactive B lymphocytes in salivary glands and peripheral blood of patients with Sjögren's syndrome. Clin Exp Immunol 115: 203-207.

22. Salomonsson S, Jonsson MV, Skarstein K, Brokstad KA, Hjelmström P, et al (2003) Cellular basis of ectopic germinal center formation and autoantibody production in the target organ of patients with Sjögren's syndrome. Arthritis Rheum 48: 3187-3201.

23. Adamson TC, Fox RI, Frisman DM, Howell FV (1983) Immunohistologic analysis of lymphoid infiltrates in primary Sjogren's syndrome using monoclonal antibodies. J Immunol 130: 203-208.

24. Geissmann F, Manz MG, Jung S, Sieweke MH, Merad M, et al. (2010) Development of monocytes, macrophages, and dendritic cells. Science 327 656-661.

25. Bacman S, Perez Leiros C, Sterin-Borda L, Hubscher O, Arana R, et al. (1998) Autoantibodies against lacrimal gland $\mathrm{M} 3$ muscarinic acetylcholine receptors in patients with primary Sjögren's syndrome. Invest Ophthalmol Vis Sci 39: 151 156.

26. Youinou P, Pers JO (2011) Disturbance of cytokine networks in Sjögren's syndrome. Arthritis Res Ther 13: 227.

27. Kyriakidis NC, Kapsogeorgou EK, Tzioufas AG (2014) A comprehensive review of autoantibodies in primary Sjögren's syndrome: clinical phenotypes and regulatory mechanisms. J Autoimmun 51: 67-74.

28. de Wilde $\mathrm{PC}$, Kater $\mathrm{L}$, Bodeutsch $\mathrm{C}$, van den Hoogen $\mathrm{FH}$, van de Putte LB et al. (1996) Aberrant expression pattern of the SS-B/La antigen in the labial salivary glands of patients with Sjögren's syndrome. Arthritis Rheum 39: 783791.

29. Tzioufas AG, Kapsogeorgou EK, Moutsopoulos HM (2012) Pathogenesis of Sjögren's syndrome: what we know and what we should learn. J Autoimmun 39: 4-8.

30. Passafaro D, Reina S, Sterin-Borda L, Borda E (2010) Cholinergic autoantibodies from primary Sjögren's syndrome modulate submandibular gland $\mathrm{Na}+/ \mathrm{K}+-\mathrm{ATP}$ ase activity via prostaglandin $\mathrm{E} 2$ and cyclic AMP. Eur J Oral Sci 118: 131-138.

31. Passafaro D, Sterin-Borda L, Reina S, Borda E (2011) Cholinergic Autoantibodies from Primary Sjögren's Syndrome Inhibit Mucin Production via Phospholipase $\mathrm{C}$ and Cyclooxygenase-2 In the Rat Submandibular Gland. Dent Res J (Isfahan) 8: 138-145.

32. Jonsson MV, Skarstein K, Jonsson R, Brun JG (2007) Serological implications of germinal center-like structures in primary Sjögren's syndrome. J Rheumato 34: 2044-2049.

33. Shiboski SC, Shiboski CH, Criswell L (2013)American College of Rheumatology classification criteria for Sjögren's syndrome: a data-driven, expert consensus approach in the Sjögren's International Collaborative Clinical Alliance cohort. Arthritis Care Res 64: 475-487.

34. Vitali C, Bootsma H, Bowman SJ, Dorner T, Gottenberg JE, et al. (2013) Classification criteria for Sjogren's syndrome: we actually need to definitively resolve the long debate on the issue. Ann Rheum Dis 72: 476-478.

35. Camusso JJ, Borda ES, Bacman S, Hubscher O, Goin JC, et al. (1994) Antibodies against beta adrenoceptors in mothers of children with congenital heart block. Acta Physiol Pharmacol Ther Latinoam 44: 94-99.

36. Bacman S, Sterin-Borda L, Camusso JJ, Hubscher O, Arana R, et al. (1994) Circulating antibodies against neurotransmitter receptor activities in children with congenital heart block and their mothers. FASEB J 8:1170-1176.

37. Borda E, Camusso JJ, Perez Leiros C, Bacman S, Hubscher O, et al. (1996) Circulating antibodies against neonatal cardiac muscarinic acetylcholine receptor in patients with Sjögren's syndrome. Mol Cell Biochem 163-164: 335341.

38. Borda E, Leiros CP, Bacman S, Berra A, Sterin-Borda L (1999) Sjögren autoantibodies modify neonatal cardiac function via M1 muscarinic acetylcholine receptor activation. Int J Cardiol 70: 23-32.

39. Borda E, Sterin-Borda L (2001) Autoantibodies against neonatal heart M1 muscarinic acetylcholine receptor in children with congenital heart block. J Autoimmun 16: 143-150

40. Bacman S, Sterin-Borda L, Camusso JJ, Arana R, Hubscher O, et al. (1996) Circulating antibodies against rat parotid gland M3 muscarinic receptors in primary Sjögren's syndrome. Clin Exp Immunol 104: 454-459.

41. Reina S, Sterin-Borda L, Orman B, Borda E (2004) Human mAChR antibodies from Sjögren syndrome sera increases cerebral nitric oxide synthase activity and nitric oxide synthase mRNA level. Clinlmmunol 113: 193-202.

42. Limas CJ, Goldenberg IF, Limas C (1989) Autoantibodies against betaadrenoceptors in human idiopathic dilated cardiomyopathy. Circ Res 64: 97 103.

43. Sterin-Borda L, Gorelik G, Borda ES (1991) Chagasic IgG binding with cardiac muscarinic cholinergic receptors modifies cholinergic-mediated cellular transmembrane signals. Clin Immunol Immunopathol 61: 387-397.

44. Iosa D, Dequattro V, Lee DD, Elkayam U, Caeiro T, et al. (1990) Pathogenesis of cardiac neuro-myopathy in Chagas' disease and the role of the autonomic nervous system. J Auton Nerv Syst 30 Suppl: S83-87.

45. Borda E, Pascual J, Cossio P, De La Vega M, Arana R, et al. (1984) A circulating IgG in Chagas' disease which binds to beta-adrenoceptors of myocardium and modulates their activity. Clin Exp Immunol 57: 679-686.

46. Pascual J, Borda E, Cossio P, Arana R, Sterin-Borda L (1986) Modification of sarcolemmal enzymes by chagasic IgG and its effect on cardiac contractility. Biochem Pharmacol 35: 3839-3845.

47. Silverman ED (1993) Congenital heart block and neonatal lupus erythematosus: prevention is the goal. J Rheumatol 20: 1101-1104.

48. Buyon JP, Ben-Chetrit E, Karp S, Roubey RA, Pompeo L, et al. (1989) Acquired congenital heart block. Pattern of maternal antibody response to biochemically defined antigens of the SSA/Ro-SSB/La system in neonatal lupus. J Clin Invest 84: 627-634.

49. Reina S, Orman B, Anaya JM, Sterin-Borda L, Borda E (2007) Cholinoreceptor autoantibodies in Sjögren syndrome. J Dent Res 86: 832-836.

50. Reina S, Sterin-Borda L, Orman B, Borda E (2005) Autoantibodies agains submandibular gland muscarinic cholinoceptor subtypes in primary Sjögren Syndrome. Eur J Inflamm 3: 135-141.

51. Liang-Xiong Fu M, Schulze W, Wallukat W, Hjalmarson A, Hoebeke J (1995) Functional epitopes analysis of the second extracellular loop of the human heart muscarinic acetylcholine receptor. J Mol Cell Cardiol 27: 427-436.

52. Tsubota K, Fujihara T, Takeuchi T (1997) Soluble interleukin-2 receptors and serum autoantibodies in dry eye patients: correlation with lacrimal gland function. Cornea 16: 339-344.

53. Albrecht C, von Der Kammer H, Mayhaus M, Klaudiny J, Schweizer M, et al. (2000) Muscarinic acetylcholine receptors induce the expression of the immediate early growth regulatory gene CYR61. J Biol Chem 275: 2892928936.

54. Von der Kammer H, Demilaray C, Andresen B, Albrecht C, Mayhaus M, et al. 
Citation: Reina S, Borda E (2014) Autoantibodies against Muscarinic Acetylcholine Receptor on Exocrine Glands in Sjögren Syndrome. Dentistry 4: 265. doi:10.4172/2161-1122.1000265

(2001) Regulation of gene expression by muscarinic acetylcholine receptors BiochemSocSymp 67: 131-140.

55. Kovács L, Török T, Bari F, Kéri Z, Kovács A, et al. (2000) Impaired microvascular response to cholinergic stimuli in primary Sjögren's syndrome. Ann Rheum Dis 59: $48-53$

56. Kyriakidis NC, Kapsogeorgou EK, Tzioufas AG (2014) A comprehensive review of autoantibodies in primary Sjögren's syndrome: clinical phenotypes and regulatory mechanisms. J Autoimmun 51: 67-74.

57. Iwabuchi Y, Masuhara T (1994) Sialogogic activities of SNI-2011 compared with those of pilocarpine and McN-A-343 in rat salivary glands: identification of a potential therapeutic agent for treatment of Sjörgen's syndrome. Gen Pharmacol 25: 123-129.

58. Nakamura T, Matsui M, Uchida K, Futatsugi A, Kusakawa S, et al. (2004) $\mathrm{M}(3)$ muscarinic acetylcholine receptor plays a critical role in parasympathetic control of salivation in mice. J Physiol 558: 561-575.

59. Li J, Ha YM, Kü NY, Choi SY, Lee SJ, et al. (2004) Inhibitory effects of autoantibodies on the muscarinic receptors in Sjögren's syndrome. Lab Invest 84: $1430-1438$

60. Ashkenas J, Muschler J, Bissell MJ (1996) The extracellular matrix in epithelia biology: shared molecules and common themes in distant phyla. Dev Biol 180: 433-444.

61. Tobin G, Giglio D, Lundgren O (2009) Muscarinic receptor subtypes in the alimentary tract. J Physiol Pharmacol 60: 3-21.

62. Murakami M, Nakatani Y, Tanioka T, Kudo I (2002) Prostaglandin E synthase. Prostaglandins Other Lipid Mediat 68-69: 383-99.

63. Yeaman C, Grindstaff KK, Nelson WJ (1999) New perspectives on mechanisms involved in generating epithelial cell polarity. Physiol Rev 79: 73-98.

64. Hayakawa Y (1998) Matrix metalloproteinases (MMPs) and tissue inhibitors of metalloproteinases (TIMPs) in the development and disease of oral tissues Dent Jpn 34: 167-177.

65. Konttinen YT, Halinen S, Hanemaaijer R, Sorsa T, Hietanen J, et al. (1998) Matrix metalloproteinase (MMP)-9 type IV collagenase/gelatinase implicated in the pathogenesis of Sjögren's syndrome. Matrix Biol 17: 335-347.
66. Juliano RL, Haskill S (1993) Signal transduction from the extracellular matrix. J Cell Biol 120: 577-585.

67. Ruoslahti E, Reed JC (1994) Anchorage dependence, integrins, and apoptosis Cell 77: 477-478.

68. Frisch SM, Francis H (1994) Disruption of epithelial cell-matrix interactions induces apoptosis. J Cell Biol 124: 619-626.

69. Mollace V, Muscoli C, Masini E, Cuzzocrea S, Salvemini D (2005) Modulation of prostaglandin biosynthesis by nitric oxide and nitric oxide donors. Pharmacol Rev 57: 217-252.

70. Kang YJ, Mbonye UR, DeLong CJ, Wada M, Smith WL (2007) Regulation of intracellular cyclooxygenase levels by gene transcription and protein degradation. Prog Lipid Res 46: 108-125.

71. Borda E, Heizig G, Busch L, Sterin-Borda L (2002) Nitric oxide synthase/ PGE(2) cross-talk in rat submandibular gland. Prostaglandins Leukot Essent Fatty Acids 67: 39-44.

72. Bacman SR, Berra A, Sterin-Borda L, Borda E (1998) Human primary Sjögren's syndrome autoantibodies as mediators of nitric oxide release coupled to lacrimal gland muscarinic acetylcholine receptors. Curr Eye Res 17: 1135-1142.

73. Orman B, Reina S, Sterin-Borda L, Borda E (2006) Signaling pathways leading to prostaglandin $E(2)$ production by rat cerebral frontal cortex. Prostaglandins Leukot Essent Fatty Acids 74: 255-262.

74. Reina S, Sterin-Borda L, Passafaro D, Borda E (2011) Anti-M3 muscarinic cholinergic autoantibodies from patients with primary Sjögren's syndrome trigger production of matrix metalloproteinase-3 (MMP-3) and prostaglandin E2 (PGE2) from the submandibular glands. Arch Oral Biol 56: 413-420.

75. Koo NY, Li J, Hwang SM, Choi SY, Lee SJ, et al. (2008) Functional epitope of muscarinic type 3 receptor which interacts with autoantibodies from Sjogren's syndrome patients. Rheumatology (Oxford) 47: 828-833.

76. Jin M, Hwang SM, Davies AJ, Shin Y, Bae JS, et al. (2012) Autoantibodies in primary Sjögren's syndrome patients induce internalization of muscarinic type 3 receptors. Biochim Biophys Acta 1822: 161-167.

77. Borda E, Passafaro D, Reina S, Sterin-Borda L (2011) Modulation of JNK by Cholinergic Autoantibodies from Patients with Sjögren Syndrome. Pharmacology and Pharmacy 2: 256-265.
Citation: Reina S, Borda E (2014) Autoantibodies against Muscarinic Acetylcholine Receptor on Exocrine Glands in Sjögren Syndrome. Dentistry 4: 265. doi:10.4172/2161-1122.1000265

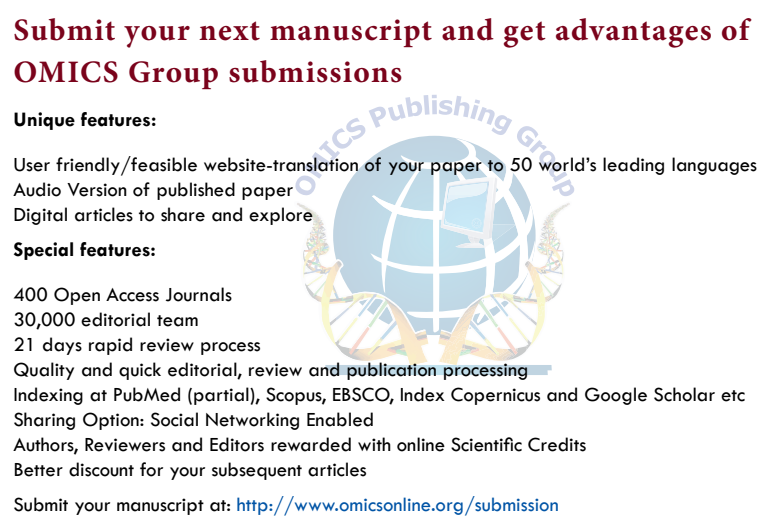

Submit your next manuscript and get advantages of OMICS Group submissions 